University of Nebraska - Lincoln

DigitalCommons@University of Nebraska - Lincoln

Faculty Publications: Department of Teaching, Department of Teaching, Learning and Teacher Learning and Teacher Education

Education

3-2007

\title{
A Dynamic Professional Development School Partnership in Science Education
}

Lawrence C. Scharmann

Follow this and additional works at: https://digitalcommons.unl.edu/teachlearnfacpub

Part of the Curriculum and Instruction Commons, and the Teacher Education and Professional

Development Commons

This Article is brought to you for free and open access by the Department of Teaching, Learning and Teacher Education at DigitalCommons@University of Nebraska - Lincoln. It has been accepted for inclusion in Faculty Publications: Department of Teaching, Learning and Teacher Education by an authorized administrator of DigitalCommons@University of Nebraska - Lincoln. 


\title{
A Dynamic Professional Development School Partnership in Science Education
}

\author{
Lawrence C. Scharmann
}

Kansas State University

\begin{abstract}
The author describes the evolution of a traditional on-campus secondary science methods course into a dynamic field- and campus-based professional development school collaboration. Whereas science teaching methods were taught in an isolated and independent course, they are now integrated within an interdependent experiential semester that carefully integrates teaching methods, professional seminars, interpersonal relations, classroom management, reading strategies, and multicultural education into a dynamic field-based curriculum for preservice teachers. A faculty team from the Kansas State University (KSU) Department of Secondary Education conducted a series of meetings to establish a collaborative climate in which to investigate the benefits of simultaneous reform of preservice teacher education and the professional development of inservice teachers. School-based teacher counterparts in mathematics and science piloted several models, performed action research, and worked toward simultaneous improvement based on a reflection or documentation, or both, of best practices. Consistent with reform initiatives identified by the National Research Council (1996), the author documents actions taken to enhance the preparation of preservice teachers at KSU.

Keywords: in-service teacher development, preservice teacher education, professional development school partnership, secondary science education
\end{abstract}

Published in The Journal of Educational Research 100:4 (March/April 2007), pp 235-242. Copyright $\left({ }_{0} 2007\right.$ Heldref Publications. Used by permission. 
Science educators recently delineated successful professional development school (PDS) partnership efforts (Eick, Ware, \& Williams, 2003); however, this success often has been limited to an implementation of PDS models at the elementary school level. With the exception of school-based placements of science methods students or other co-teaching arrangements, or both (Eick et al.), systemic PDS initiatives are more cumbersome at the secondary school level. Secondary school teachers have difficulty borrowing elementary PDS models without data that illustrate the superiority of a PDS model compared with models currently being used (Ridley, Hurwitz, Hackett, \& Miller, 2005). At the elementary level, whole school, building-wide adoption occurs fairly readily and represents the strength of the elementary PDS model. At the secondary level, however, building-wide adoption is fraught with resistance because of the various perceived needs of independent, subject-centered departments. Thus, secondary school PDS models must be successfully tailored to individual subject areas before the potential for building wide adoption can be realized.

\section{Setting the Stage for Change}

Curricular revisions in secondary science education at Kansas State University (KSU) were initiated through conversations between university faculty members and secondary school teachers. Using a theoretical context established by Goodlad (1994), Darling-Hammond (1994), the Holmes Group (1995), and the Sid W. Richardson Foundation Forum (1993), a faculty team from the Department of Secondary Education conducted a series of meetings to establish a collaborative climate in which to investigate the benefits of simultaneous reform of preservice teacher education and the professional development of inservice teachers. School-based teacher counterparts in mathematics and science piloted several models, participated in survey research, and worked toward simultaneous improvement based on a reflection or documentation, or both, of best practices. Consistent with reform issues identified by the National Research Council (1996), the author delineates actions taken to enhance the preparation of preservice science teachers at KSU and professional development of local in-service teachers. 


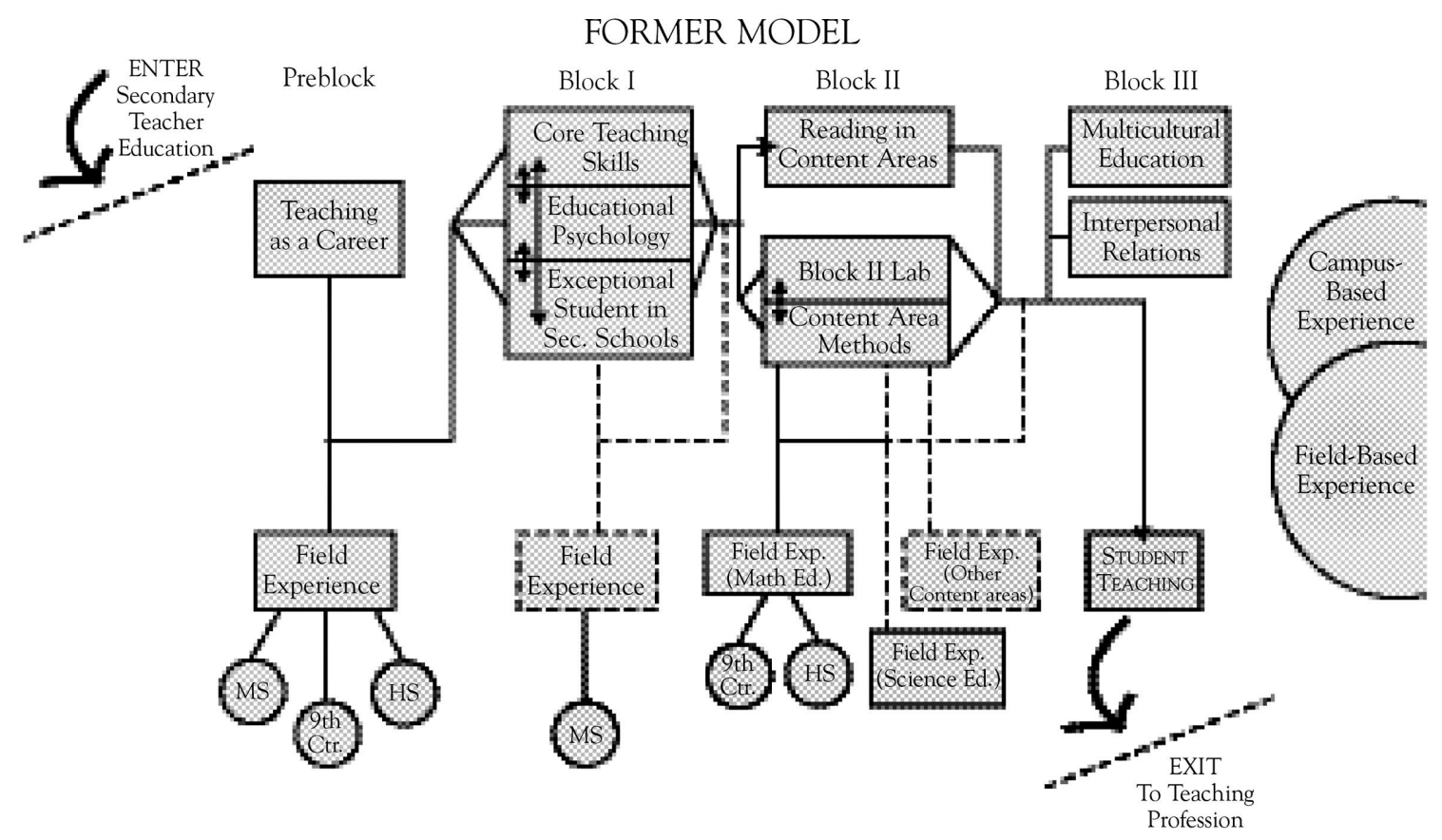

Figure 1. Professional education sequence at Kansas State University, 1988-1997. MS = middle school. HS = high school. 9th Ctr = Manhattan High School, East Campus, for Grade 9 students.

\section{Program Evolution}

The notion of having secondary preservice teachers spend actual time in a school-based environment prior to the student-teaching semester was still a novelty at KSU in 1988 (see Figure 1, Former Model, Teaching as a Career). Even then, preservice teachers rarely did much other than grade papers, make copies, record grades, and play the role of teacher's aide. Thirty clock hours in a high school or middle school classroom was better than none at all; however, as a means to foster behavioral changes in preservice teachers from "thinking like college students" to "thinking like professional teachers," the experience accomplished very little. The problem was not that the experience was ill conceived but rather that it was performed as a one semester, isolated episode. Once completed, KSU education students spent no additional time in schools before the student-teaching semester. The gains that preservice teachers might have accomplished in understanding target learners were not reinforced, and, therefore, in most 
cases, they were simply lost. In follow-up surveys, KSU teacher education graduates remarked that in some cases they were not ready to learn from the early field experience because they enrolled in it too early in their program. In other cases, mature students eager to apply insights gained from school-based experiences were disappointed that they would spend no additional time in schools before being assigned to work with a teacher during their student teaching semester.

Casual conversations and subtle suggestions between local school district teachers and KSU faculty promoting change did not improve the lack of transition for preservice teachers between the 1989-1993 academic years. Even a series of planned meetings during the 19931995 school years between local school district subject-area department heads and KSU faculty representing corresponding subject area teaching methods failed to produce consensus for substantive change. The dean of the KSU College of Education was on the verge of relinquishing the PDS concept at the secondary school level because of a climate of resistance that emanated from both educational levels.

The first opportunity to make substantive inroads occurred in 1995, when a KSU secondary methods professor, representing the mathematics discipline and fully engaged in promoting change toward a field-based model, received a year-long sabbatical leave. The professor encouraged the department chair of Secondary Education (who represented the discipline of science and was also keenly interested in a field-based teacher-education model) to solicit the cooperation of Manhattan High School (MHS) to release a mathematics teacher half time to teach mathematics teaching methods and supervise mathematics student teachers. The ease with which the initial collaborative effort succeeded did not surprise either the mathematics teacher or the KSU department chair because both were graduates of the same institution-one that had implemented school-based experiences for methods students 25 years earlier. At that point, KSU and school district partners began to conceive of additional school-based time for preservice teachers during the 1995-1996 school year. The additional conceptions are represented in Figure 1 by dashed lines associated with Blocks I and II.

The KSU department chair (who also serves as the science teaching methods professor) and MHS mathematics teacher continued to hold informal meetings with several science teachers who had expressed 
interest in the progress of this pilot collaboration. During those informal meetings, a major source of the resistance to previous PDS conversations emerged. District-level teachers and university faculty, although respectful of one another, were not sufficiently part of one another's worlds. Science educators at MHS and KSU decided to change that situation with the support of the College of Education dean and Unified School District 383 (USD 383; Manhattan-Ogden) superintendent of schools. The initial plans to increase the time spent in one another's worlds is represented in Figure 1 by the partially overlapping semicircles appearing on the right-hand side.

\section{Shared Resources and Mutual Support}

Content-area teaching methods represent the major focus of the Block II semester courses (see Figure 1). The intent of Block II is to help preservice teachers plan and implement instructional considerations specific to a subject of study (i.e., science content, state and national science standards, etc.) and initiate a forum to introduce reading strategies and to use graphic organizers. Plans to revise the content-area teaching methods experiences were initiated during the summer of 1995. Negotiations, however, took place over the course of the subsequent fall semester. One major set of negotiations centered on the items that the KSU science methods professor would give up to gain access to school-based experience time for his students. Another set of negotiations involved the manner in which the methods professor might be involved in the science teacher's classroom, and vice versa. Finally, the professors needed to jointly determine how to involve other science teachers from MHS in the collaboration to enhance ownership and diminish resistance. They ultimately arrived at the following set of parameters.

\section{Parameters of Collaboration (Course Schedule)}

1. From a three-credit methods course-To a three-credit methods course and accompanying one-credit laboratory or school-based field experience;

2. From two, 110-min sessions per week-To methods course and laboratory meeting for three, 110-min sessions on the KSU campus for the first 6 weeks and the last week of the semester; From 16 
weeks' duration-To methods course meeting as a weekly seminar; students in high school science classrooms $2.5 \mathrm{hr}$. per day for 3 consecutive days during Weeks 7-15;

3. No school-based field experience.

Sharing resources and building trust. The science department nominated one of their teachers to serve as a clinical instructor to represent them in collaboration with the KSU science teacher educator. The district choice was exceptional because the individual selected was popular, enthusiastic, dynamic, and experienced; she was also respected for stating reasoned opinions and for serving as an advocate for the concerns of fellow teachers. She was, in addition, willing to disagree with her colleagues when they were misinformed. The clinical instructor spent a minimum of one class session each week participating in or co-teaching, or both, the on-campus science teaching methods experiences. Conversely, the KSU professor spent several class periods each week in the high school discussing issues related to the collaboration, visiting with teachers informally, and occasionally assisting the clinical instructor during laboratory instruction. Finally, both individuals facilitated and attended each of the professional seminars presented by district science teachers. That sharing of resources promoted mutual trust and respect for one another. It also enhanced their capacity to build a friendship.

Jointly determining preservice teacher placements. The clinical instructor and KSU professor, as a consequence of spending more time in one another's milieus, gained the ability to productively discuss prospective matches between preservice and in-service science teachers for the 9 weeks of the semester in which preservice teachers worked in a school-based environment. They quickly found that when the matches worked, which occurred with great frequency, both parties often wanted to continue their working relationship through the student-teaching semester.

Increasing science teacher ownership and participation. The clinical instructor solicited science teachers at each of the four secondary schools in the USD 383 district (two middle schools, two high school campuses) to participate in the Block II science collaboration on two levels. The first level was accepting responsibility for mentoring a science preservice teacher (i.e., methods student) for the 1-2 
class periods over 3 consecutive days for the 9 weeks spent in the school environment. The second level was considering the presentation of a professional seminar to preservice teachers on a topic of expertise (e.g., cooperative learning, learning preferences, alternative assessment). Some science teachers agreed to participate on two levels, some teachers settled on one level, and still others wanted to opt out of any involvement. In each case, the clinical instructor honored wishes of the science teachers. After careful consideration, the clinical instructor and KSU professor selected seminar speakers; the instructor subsequently invited individual speakers.

Confronting misinformation. Neither the KSU professor nor the clinical instructor allowed misinformation to stand, rumors to start, or negative attitudes to go unchecked. They agreed to confer with one another as soon as was practical after each confrontational situation. In that manner, individuals who enjoyed the resistance game of "divide and conquer" ultimately encountered a united front. The clinical instructor handled troubleshooting in the school-based environment, whereas the KSU professor did so in the university environment. Thus, strong lines of communication were opened and maintained among all relevant stakeholders-preservice and in-service teachers, clinical instructor, and KSU professor.

\section{Growing Pains and Use of Survey Research}

Two anecdotes provide a backdrop for the manner in which confrontations were handled and resistance diminished. The first situation frames the key role played by the clinical instructor in confronting misinformation and the consequential actions of the KSU professor; the second situation illustrates the actions taken by the clinical instructor in response to the KSU professor playing the role of confronter.

\section{Frame 1: The Cynic}

The first solicitation by the clinical instructor for interest among her colleagues in accepting a methods student and presenting a seminar evoked the following comment: "So . . . are the profs on-campus finally realizing they have no clue about how to prepare teachers? Is 
that what this PDS partnership is all about-trying to get us to do their job for them?" The response of the clinical instructor was calm, defusing, and simultaneously invitational:

I would have agreed with your comment in the not too distant past, however, now that I am a part of the experiences conducted on campus, I have changed my mind. Not only do they have a good notion what they are doing, they are attempting to recognize that our involvement can improve on what they already do well. Instead of dismissing this effort, I think we should embrace it, ride it, and see where it takes us. The KSU Professor wants our input ... let's take a chance.

The KSU professor knew of the comment and took a slow, steady approach with the teacher-he purposely dropped by his classroom and engaged him in conversation in the hall and lunchroom during his visits to the high school. The steady time and effort paid dividends, especially when, put to the test to supply information concerning the Third International Mathematics and Science Study, American Association for the Advancement of Science [AAAS] recommendations reported in Science for All Americans (AAAS, 1990), and data to support the benefits of inquiry teaching, the KSU professor came through each time that he was asked. The teacher gained a measure of respect for the KSU science education program, eventually accepting a methods student and student teacher into his classroom. Now, years later, the cynic looks forward to the informal visits by the KSU professor.

\section{Frame 2: The Science Content Purist}

Peers highly regarded the "science content purist" as an exceptional teacher. He brought excitement, charisma, and accuracy to every topic he presented. His rapport with students was second to none in the entire high school. He succeeded as a teacher in spite of the mediocre experiences that he remembered from all of his undergraduate courses in professional education. He always assumed, as a result of his personal experiences, that all College of Education faculty members were weak professors by nature, so he affiliated strongly with the Biology Department faculty at KSU. He had worked with the KSU professor who taught science teaching methods in an evolution workshop 
several years earlier and believed that he was a bit of an exception to his general rule concerning College of Education types. However, he assumed that the program the professor represented was still weak, at least compared with Biology Department programs. Thus, such catch phrases as "less is more" greatly irritated him; he assumed that the science methods professor would automatically recite such platitudes.

In one of the seminars for preservice teachers, the purist could not wait to state how much he disagreed with such catch phrases. ... "I am sure that your instructor has shared the motto of 'less is more' but what you will hear from me today is how strongly I disagree with this. I am a classic 'More is More' type of teacher. The more content, the better!" Instead of the expected defensive posture that he anticipated from the KSU professor, he received a carefully crafted confrontation of his statement. Waiting until the end of an otherwise excellent seminar, the KSU professor stated,

Please be careful not to make judgmental statements concerning what I have or have not taught my students, during your seminar presentation, because it tends to undermine me when I know that was not your intention. Although I have never used the catch phrase "less is more" with my students in methods class, my students are nonetheless familiar with the general philosophical approach it implies.

The content purist agreed not to undermine, but stated that that statement did not change his low opinion of the approach. The KSU professor calmly stated,

That surprises me ... because there is not a single teacher at Manhattan High School that better exemplifies the "Less is More" philosophy than you do. If you don't believe me, perhaps you might be interested in learning what the philosophy is before you make pronouncements about it.

The KSU professor discussed the problem with the clinical instructor. They decided to invite the purist back for subsequent seminars. With the assistance of the clinical instructor, the purist was carefully supplied with further information from the American Association for the Advancement of Science concerning Project 2061 (AAAS, 1990) 
and the National Science Education standards. Eventually, the purist stopped making the negative remarks that he had made previously, and, instead, concentrated on making outstanding seminar presentations that supported the intentions of the KSU science teacher education program. The consistent quality of the students from the KSU science education program with whom he worked provided the final evidence over time. The clinical instructor continually reinforced that quality by directly soliciting the purist's reactions concerning improvements in student preparedness. Because he did not want to argue with the preponderance of the evidence, the purist became a full and staunchly supportive partner in the PDS collaboration.

\section{Collection and Use of Survey Research Data}

Several data sources, including a research report on the effectiveness of variations in teacher preparation (Darling- Hammond, Chung, \& Frelow, 2002), served as a lens through which we interpreted the relative merits and problems encountered as we implemented changes in the Block II experiences. Sources included, but were not limited to:

1. KSU students' open-ended written comments, on completion of the new school-based methods experiences;

2. KSU students' open-ended written comments on completion of their student-teaching experiences; Science teachers' verbal comments made informally to the clinical instructor and KSU professor and formally to the National Council for the Accreditation of Teacher Education on-site visitation team members; Written and verbal comments taken from school district personnel officers interviewing KSU students for teaching positions; USD 383 data collected from MHS students, parents, and teachers with respect to the PDS partnership;

3. Faculty comments concerning rewards and dislikes with changes in the program.

The results of compiling, comparing, contrasting, and interpreting results from each data source yielded a fairly unanimous claim that improvements had been made- some of them vast. One example of those improvements came from parents and students in the school district. In the past, students and parents expressed resentment 
concerning the MHS students' experiences with so many unqualified student teachers. Now, students and parents express thanks for the additional assistance that was available for the semester prior to student teaching and the general improvement of the student teachers.

Another example of notable improvement was cited by the teachers who were working with KSU student teachers. In the recent past, teachers believed that they invested far too much time with a student teacher, only to gain a few weeks of quality assistance during the student-teaching semester. Teachers working with a KSU methods student prior to having that same KSU student as a student teacher, however, noted that such an early investment produced a student teacher ready to handle professional responsibilities for virtually the entire student-teaching semester.

Several major issues that stakeholders needed to address in the nascent PDS collaboration, nonetheless, also emerged from the data that we analyzed. The following groups expressed major concerns:

1. Science teachers: Suggested shortening the gap between the time when methods students ended their time in schools and when they returned as student teachers. In the former model (see Figure 1), students had 12 weeks of student teaching because the courses in Multicultural Education and Interpersonal Relations were provided during the first 4 weeks of the student-teaching semester.

2. KSU students: Suggested that because they were already spending a significant amount of time in the schools during the Block II semester, they might benefit from having the Multicultural Education and Interpersonal Relations classes better coordinated with their time in the schools.

3. Professors: Expressed concerns that their additional time in service to schools would not be rewarded, especially when tenure and promotion standards demanded the production of peer-reviewed publications over school-based service. Ginsberg and Rhodes (2003) performed a study of those concerns.

\section{Realigning Professional Program Elements}

The PDS stakeholders addressed the first two concerns almost immediately because a commitment was honored at both educational 


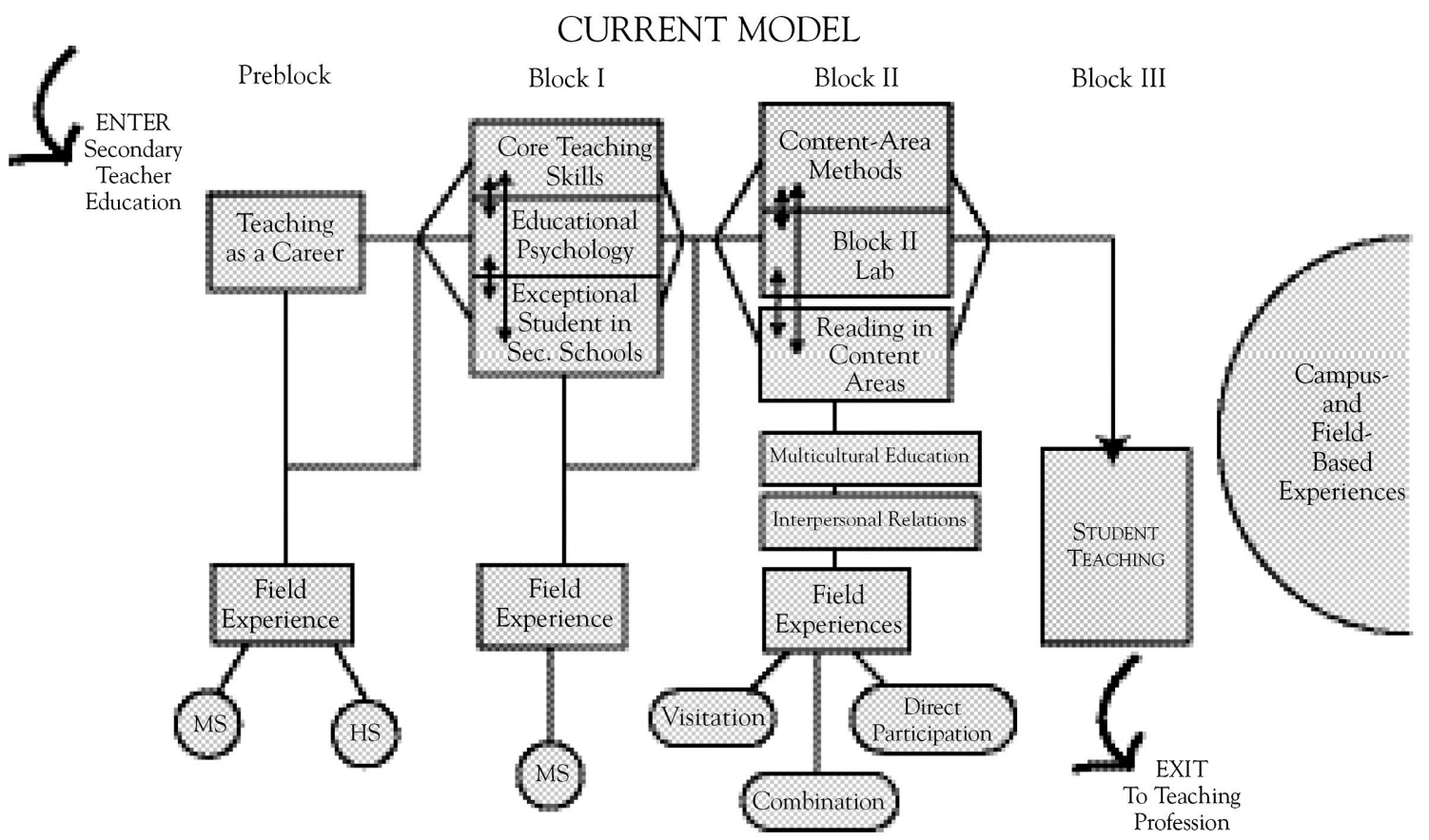

Figure 2. Professional education sequence at Kansas State University, 1997-present. MS = middle school. HS = high school.

levels to maintain a continuous improvement model. Continuous improvement necessitated fairly quick action, albeit while the Secondary Education Department Chair remained cognizant of university guidelines through which curriculum changes would need eventual approval. Figure 2 shows the changes that the Department of Secondary Education proposed, deliberated, and adopted to address the major issues listed in the preceding paragraph.

Response to the teachers' concern regarding the gap between when science methods ended and when student teaching began resulted in an extended student-teaching semester from 12 to 16 weeks (i.e., a full semester). In the new arrangement, student teachers reported to schools on the same schedule as did teachers to whom they were assigned. In the former model, student teachers reported 4 weeks after a new school year or semester began. Secondary Education faculty responded simultaneously and out of necessity to student concerns in terms of the curricular sequencing of course experiences in Multicultural Education and Interpersonal Relations. In transitioning to a full semester, 16 -week student-teaching experience, the 4 weeks dedicated 
to the two courses at the front end of the 12-week student-teaching experience had to be moved back to the Block II semester or taken as independent courses.

Faculty members, involved in teaching their respective courses, responded to student concerns and suggestions made by the chair of Secondary Education regarding how best to address course realignment. With additional KSU student and faculty input, the Department of Secondary Education reconfigured the courses and melded them into the Block II semester as an interdependent curricular arrangement. Multicultural Education was placed in the first 8 weeks of the Block II semester and Interpersonal Relations in the second 8 weeks.

Addressing the third concern voiced by KSU faculty is a matter of ongoing negotiation within the structure of the university. Faculty members and administrators intimately associated with the PDS model recognize that improvement in undergraduate teacher preparation made by KSU faculty members devoting more time to schoolbased service and simultaneous renewal cannot come without a price-that of spending time away from traditional on campus scholarly pursuits. Administrators and faculty less familiar with the intense time demand of the PDS model are more slowly accepting action research (i.e., school-based class or curricular-based projects) and original creative curriculum development as legitimate scholarly pursuits. That acceptance is not only true on our campus but also nationally (Ginsberg \& Rhodes, 2003).

\section{Extending the PDS Model}

Immediate reinforcement for the nascent secondary PDS model occurred in 1999 when the U.S. Department of Education awarded a grant to the KSU College of Education to extend mutual benefits for simultaneous improvements. Content-specific teams added the participation of crucial allies in the College of Arts and Sciences to our college and departmental teams of education faculty and secondary school counterparts. The grant permitted, among many benefits, the opportunity for KSU to create and implement a variety of fieldbased models in every academic discipline. Thus, although science (and mathematics) education pioneered curriculum revisions in KSU secondary education, specific subject disciplines demand recognition 
of constraints imposed and advantages conferred by those special milieus represented by agriculture, art, business, English/language arts, family/consumer sciences, mathematics, modern language, music, science, and social science education. Each of those disciplines uses a different, yet commensurate, approach to providing quality field experience opportunities. Three models can best represent the major field-based approaches used in the various disciplines: direct participation, visitation, or combination. Each of those models is designed and implemented as collaboration between practicing school personnel and university faculty.

In the direct participation model, students taking a content- area methods class in their major discipline work with a cooperating teacher in a PDS district for 3-4 days, one to two class periods per day, for 7-10 weeks. The responsibilities assigned to KSU student participants vary by discipline but generally include small-group and largegroup instruction, tutorial opportunities, professional collaboration and team teaching, and reflective observation. Because each secondary education KSU student participant is enrolled in courses in Multicultural Education and Interpersonal Relations concurrently with discipline-specific methods, they can observe, implement, and reflect on multicultural issues and classroom management models as direct complements to practicing pedagogy relevant to their major discipline. The direct-participation model is used by students in English/ language arts, family and consumer sciences, mathematics, modern language, and science education.

In the visitation model, methods students have multiple opportunities to visit (as a whole class, small groups, pairs, and individuals) classroom teachers of high repute as they implement specifically identified instructional models (e.g., cooperative learning, whole-class oral presentation). In addition, KSU student visitors participate in field trips to informal education sites, which enhance regular curricular offerings. The visitation model is used by students in art, music, and social sciences education.

The third, or combination model, reflects the unique character of the disciplines of agriculture and business, which must use multiple sites at greater distance from campus than a discipline such as mathematics. Whereas science teachers may number 10-20 in USD-383 secondary schools alone, agriculture may have only one educator. Thus, 
to permit KSU student participants to gain a diverse set of opportunities, the students must use more than one school site to access sufficient numbers of teachers. Therefore, a combination of formal visits, coupled with rotations of small groups of students to each of four school sites, provides an orientation to the unique skills of four teachers and permits KSU methods students help implement carefully sequenced, field-based lesson opportunities.

Finally, another important consequence of the grant was manifest in our opportunity to extend the secondary partnership to Geary County School District (Junction City), adding one additional high school and two middle schools. The inclusion of Junction City schools has been vital because it permits field placements in a school district possessing a higher percentage of diverse learners than does Manhattan. When the 5-year grant ended in 2005, PDS stakeholders took appropriate steps to assure a continued institutional partnership between KSU and school districts in Manhattan and Junction City. Each year, KSU and each respective school district superintendent drafts and signs a formal Memorandum of Agreement.

\section{Summary Reflections and Future Directions}

I described the evolution of a traditional on-campus secondary methods course into a dynamic field- and campus-based collaboration. Figure 2 shows the seamless nature of the revised set of experiences by a single semi-circle in which faculty from both education levels participate in one another's work environment. Whereas science teaching methods once was an isolated and independent course, it is now an interdependent experiential semester that carefully integrates teaching methods, professional seminars, interpersonal relations, classroom management, reading strategies, and multicultural education into a dynamic field based curriculum for preservice science teachers. Survey data continue to provide positive evidence of the deeper satisfaction that KSU preservice teachers have concerning their professional education curriculum. A notable finding concerning classroom management became quickly apparent. In the past, poststudent-teacher survey data indicated the insufficiency of the KSU program to prepare candidates to handle classroom management. In 
the revised mode, however, student teachers are satisfied with their preparation to enter the classroom because they experience the means to handle the situations in the revised Block II curriculum before student teaching.

The creation of a continuous improvement model implies constant monitoring, vigilance, communication, and responsiveness. PDS stakeholders have found that as each aspect of our professional program improves, preservice candidates demand the next revision in a manner consistent with that expressed by Darling-Hammond (2006). Future directions and issues that stakeholders need to solve include:

1. Determine how to better integrate the Reading in the Content Areas course. Although curriculum materials adopted for the course are excellent, preservice teachers still are skeptical about the value placed on the strategies provided, compared with the instructional best practice that they receive (and see modeled) in the Content Area Methods course.

2. Gain greater consistency among teachers with whom science methods students are placed during the Block II semester in terms of opportunities granted to actively be an instructional resource.

3. Document the greater effectiveness of PDS-model graduates versus non-PDS graduates from the PDS program. Castle, Fox, and Souder (2006) asserted that PDS graduates influenced student learning more quickly and reliably than did non-PDS graduates. How well do our graduates influence student learning? Early data analysis from final student teaching portfolios (begun in 2004) encourage stakeholders to believe that student teachers from KSU have a positive impact on student learning; however, data trends over time are needed to more fully appreciate this impact.

4. Create a handbook or primer for clinical instructors or school district administrators, or both, regarding the PDS collaboration. With a turnover of a superintendent, principal, or critical clinical instructor on the school-based side or similar administrator or content area methods instructor, or both, on the campus-based side of a partnership, institutional memory is potentially quickly lost. 
Acknowledgments - The author gratefully acknowledges the critical voices of four individuals in the development of the PDS secondary science education model: Drusilla (Dru) Clarke, Patricia (Tish) Simpson, Sally Yahnke, and M. Gail Shroyer. Dru and Tish, secondary science teachers, served as partners in the development of the PDS science model and its evolution. They each also served as clinical instructors to facilitate interdependence and simultaneous renewal of on- and off-campus experiences for preservice and in-service teachers. Sally Yahnke, faculty colleague in secondary teacher education, read, discussed, and provided insights on every program change being considered prior to introducing them to the collective faculty. Finally, Gail Shroyer, as KSU College of Education Coordinator of Professional Development Schools, served as the most salient critical voice to encourage us to revise, rethink, and refine our model on the basis of best practice and available reform literature. Her counsel was wise, her insights integrated, and her contribution immense.

\section{References}

American Association for the Advancement of Science. (1990). Science for all Americans - Project 2061. New York: Oxford University Press.

Castle, S., Fox, R. K., \& Souder, K. O. (2006). Do professional development schools (PDSs) make a difference? A comparative study of PDS and non-PDS candidates. Journal of Teacher Education, 57, 65-80.

Darling-Hammond, L. (1994). Professional development schools: Schools for developing a profession. New York: Teachers College Press.

Darling-Hammond, L. (2006). Assessing teacher education. The usefulness of multiple measures for assessing program outcomes. Journal of Teacher Education, 57, 120-138.

Darling-Hammond, L. Chung, R., \& Frelow, F. (2002). Variation in teacher preparation. How well do different pathways prepare teachers to teach? Journal of Teacher Education, 53, 286-302.

Eick, C. J., Ware, F. N., \& Williams, P. G. (2003). Co-teaching in a science methods course: A situated learning model of becoming a teacher. Journal of Teacher Education, 54, 74-85.

Ginsberg, R., \& Rhodes, L. K. (2003). University faculty in partner schools. Journal of Teacher Education, 54, 150-162.

Goodlad, J. I. (1994). Educational renewal. San Francisco: Jossey-Bass.

Holmes Group. (1995). Tomorrow's schools of education. East Lansing, MI: Author.

National Research Council. (1996). National science education standards. Washington, DC: National Academy Press.

Ridley, D. S., Hurwitz, S., Hackett, M. R. D., \& Miller, K. K. (2005). Comparing PDS and campus-based preservice teacher preparation. Is PDS-based preparation really better? Journal of Teacher Education, 56, 46-56.

Sid W. Richardson Foundation Forum. (1993). The professional development school. Fort Worth, TX. 